\title{
Promotional Strategy for Magic Group Media
}

\author{
Melia Lohanjaya ${ }^{1,2}$ \\ ${ }^{1}$ Art and Technology, Faculty of Academie Creatieve Technologie, Saxion University of Applied Sciences, \\ M. H. Tromplaan 28, 7513 AB, Enschede, The Netherlands \\ 2Desain Komunikasi Visual, Fakultas Seni dan Desain, Universitas Kristen Petra, \\ Siwalankerto 121-131, Surabaya \\ Email: melialohanjaya@gmail.com
}

\begin{abstract}
Magic Group Media is a post-production company based in Amsterdam. Magic Group Media constantly keeps growing and being ambitious in a way to expand the business and target a wider market. Magic has already done some promotion strategies before, but to reach a bigger market, Magic evaluates it is essential to invest more in effective promotional strategy. Through this promotional strategy, Magic wants to build a working relationship with new potential clients. This study is aimed at analyzing and knowing what promotional strategy can be used by Magic Group Media to build a working relationship with potential clients.
\end{abstract}

Keywords: Promotional strategy, Promotional Mix, Magic Group Media.

\begin{abstract}
Abstrak
Magic Group Media adalah perusahaan pasca-produksi yang berbasis di Amsterdam. Magic Group Media terus berkembang dan menjadi ambisius untuk memperluas bisnis dan menarget pasar yang lebih luas. Magic Group Media telah melakukan beberapa strategi promosi sebelumnya, tetapi untuk menjangkau pasar yang lebih besar, Magic mengevaluasi bahwa penting untuk berinvestasi lebih banyak dalam strategi promosi yang efektif. Melalui strategi promosi ini, Magic ingin membangun hubungan kerja dengan klien potensial baru. Penelitian ini bertujuan untuk menganalisis dan mengetahui apa strategi promosi yang dapat digunakan oleh Magic Group Media dalam rangka membangun hubungan kerja dengan klien potensial.
\end{abstract}

Kata kunci: Strategi promosi, Promotional Mix, Magic Group Media.

\section{Introduction}

Magic Group Media is a post-production company based in Amsterdam. Magic was founded by Edwin and Peter in 2000. The company is a content creation company which focuses on post-production as core business and is now still growing. The services consist of photo editing (retouching, coloring, manipulation, etc), and 3D modelling/CGI. With photo editing as the core business, the products they deliver are imageries which are used by the clients as advertising images, magazines, photography artworks, etc. Most of 3D they make are part of the imagery. Magic combines photo editing with 3D modelling to provide the best imagery for the clients. The company has a team of 10 workers, which consists of 2 creative directors, 1 general manager, 2 sales marketing, 4 digital artists ( 2 senior operators, 1 mediator operator, and 1 junior operator), and $13 \mathrm{D}$ artist.
Here are some examples of Magic's works:

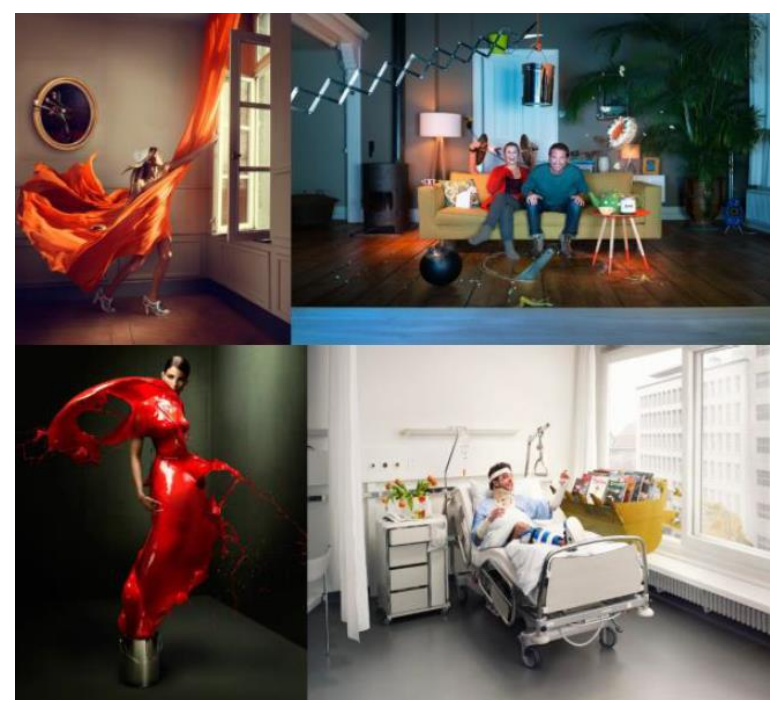

Figure 1. Magic Group Media’s works 


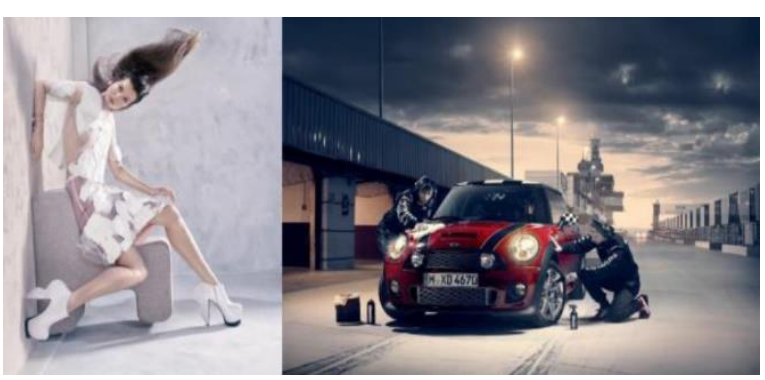

Figure 2. Magic Group Media's works

As a post-production company with a very good reputation and many loyal clients, in order to constantly keeps growing and expand the business to a wider market, Magic needs more new potential clients. Magic has done some promotional strategies which work well with the existing clients: partaking in some industry events, the occasional party, the occasional paid promotion, and direct presentations to clients.

In order to reach a bigger market, Magic evaluates it is essential to invest more in effective promotional strategy. Through this promotional strategy, Magic wants to build a working relationship with new potential clients.

\section{Method}

The below-mentioned methods are used in this study:

\section{In-depth Interview}

Interview with the company supervisor gives the relevant and actual insight about the company itself, also the problem and the objectives of this study. The interview is done by question and answer between the interviewer and the informant.

\section{Desk Research}

Data is obtained from literature books and articles that provide relevant contents and information regarding the promotional strategy.

\section{Concept Development}

The final definition of the problem is that Magic feels that they haven't reached their full potential in their promotion strategy in acquiring new potential clients and is looking for a way to attain that objective. strategy to increase the conversion rate and decrease the bounce rate.

The goal of this study is to create an effective promotional strategy for Magic Group Media to build a working relationship with new potential clients. There are several essential factors that should be taken into consideration to establish an effective promotional strategy, which are:

\section{Define Stage in the Product Lifecycle}

Different stages of the product life cycle require different types of promotional activities and strategies.

\section{Define Nature of the Product}

Different types of products require different promotional tools and influence the promotional mix.

\section{Define Competitor Actions}

To be successful, a company needs to provide greater customer value and satisfaction than its competitors do.

\section{Define the Target Audience Profile}

The people who make up the target market need to be considered before committing to a promotional mix.

\section{Define the Message}

Deciding what image (perception) you want to show with your product or service.

\section{Determine the Promotional Mix}

To establish an effective promotional strategy, it's important to choose particular promotional mix elements instead of using all of them, according to the factors that affect the promotional mix, which are stage in product life cycle, nature of the product, the characteristics of target market, and the competitors' actions.

\section{Result}

\section{Stage in the Product Lifecycle}

Magic is now in Growth phase because Magic's promotional strategy characteristics are to increase brand awareness, create strong brand equity, foster long term customer loyalty, and promotion is aimed at broader audience (new potential clients).

\section{Nature of the Product}

Type of service Magic offers are classified into business product/services because the products/services they deliver are not directly used by the clients, but more for commercial and for the client's client. Also, the products are often custom-tailored to the client's exact specifications and needs, therefore they are often not well suited to mass promotion.

\section{Competitor Actions}

1. Participating in some events to show existence and get in touch with new potential clients.

2. Pinning not only portfolio works but also relevant, inspiring, and well-organized contents/ images on Pinterest. 
3. Pinning portrait images on Pinterest that are better-looking and more engaging visually compared to landscape images to present a good impression to the audience.

4. Communicating the brand value on the website to make the visitors aware what Magic care about, that Magic has this value they believe in and stand for.

5. Putting a 'share' button on the portfolio images on website in order to integrate social networks and sharing on the website.

6. Putting contact form/box on website, so visitors of the website can directly send message through that form without going to their email program.

7. Giving short description about the works/portfolio images they post on the website so visitors can understand what have done and Magic's part on the image.

\section{The Target Audience Profile}

a. People within the brands, agencies:

- Brand managers

- Marketing managers

- Art directors

b. Photographers

They are man and woman, live in Netherlands. They are also professionals, creative, result driven, socially engaged, visually oriented (active in Facebook, Pinterest, and Instagram), interested in art and design, and have many connections and relations.

\section{The Message}

The message that wants to be communicated to the audience is the brand value of Magic itself, which is: "We believe in the power of image, we believe in high quality image. High quality image can make you stand out from the crowd, draw your attention, touch you in a world of imaging emotion, and will definitely represent you better. That's why we work in this high level of details, quality, and services to make it a high quality and professional image for you and that makes us masters of imagery because we create imagery."

\section{The Promotional Mix}

\section{Public Relations}

Magic needs public relations in a form of event. Through an event, Magic can communicate their brand value through keynote speaker and exhibition to attract and reach the target audience personally and professionally.

To communicate the brand value of Magic and meet the target audience's needs, there are two essential criteria for Magic's event: a. Keynote speaker

Through a keynote speaker, Magic can give a seminar or talk show to share their brand value about what they believe in high quality image, vision, and represent themselves as a professional.

b. Exhibition

Adapting from the competitors' promotional strategy, beside a keynote speaker, doing an exhibition is also part of communicating Magic's brand value, at the same time present Magic as a professional through showing their best works during the exhibition.

\section{Personal selling}

As personal approach to their clients is important for Magic to fulfill the needs of the clients, and result in positive outcomes (loyal clients), therefore personal selling is important for Magic. Face to face communications remain the most powerful way of transmitting a message from one person to another (Gibson, 2015).

According to Lamb Marketing, the best way to do the personal selling is by doing relationship selling. Relationship selling or consultative selling which emphasizes personalization and empathy as key ingredients in identifying prospects and developing them as long-term, satisfied customers. Thus, Magic's focus is not on selling products but on building mutual trust through the delivery of longterm, value-added benefits to the customers by becoming consultants, partners, and problem solvers for their customers.

\section{Internet Marketing}

Due to the target audience's active online, it's essential for Magic to connect with their target audience online, which can be done through social media platforms and the website of Magic. The online media of Magic which are social media platforms and the website are all integrated one another to generate more visitors.

\section{Social Media}

\section{LinkedIn}

In accordance with the target audience who have LinkedIn account for business purposes, Magic should take LinkedIn into account as one of their promotional strategy.

Thus, it's essential for Magic to make some improvements on their LinkedIn profile, such as:

1. To build first professional impression, Magic should put their official logo on their LinkedIn profile. 
2. Encourage existing clients to give recommendations on Magic's LinkedIn profile. Recommendations will make account more credible and reliable.

3. Put a description about the brand value of Magic to make the visitors aware what Magic care about, that Magic has this value they believe in and stand for.

4. Post at least once, or a few times a week, with content that will bring people to Magic's company page.

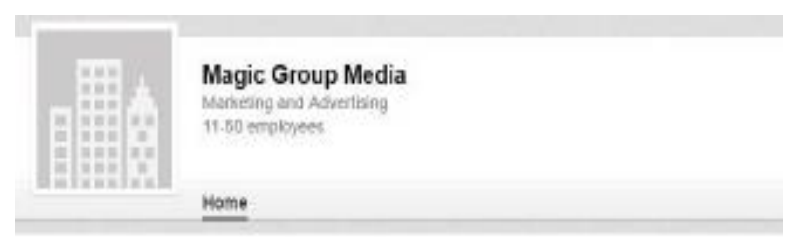

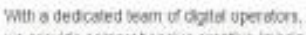

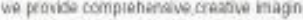

services atich are gupported ty indong

stardardeed colour management and digka protory

As a scurce of usabuty we have nastersed the

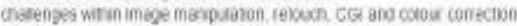

Cus semoe ndudes

Scanning isibes poarciss regatues ext

distal mape processing of ras dota, olgtal pronthy

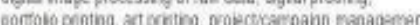

on bcalion digiat image sapport

\section{Recent Updates}

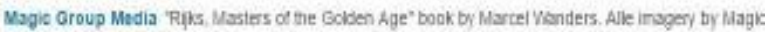

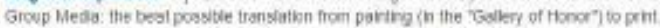

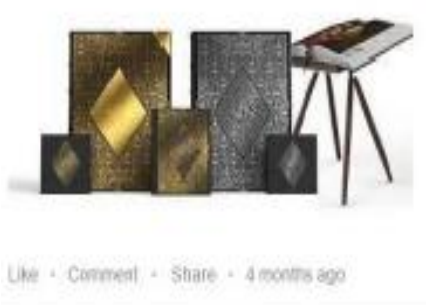

Wygio Group Media we dont do Jus very oten UkLEss rs scmeding really specal so I thirk this is a ussted bosst post. Wagit Group Meda iesponsible for all insoery in the Fols, Masters of the Goiden

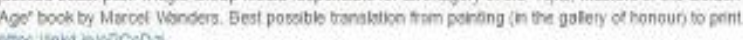
Goe inning inePGCD

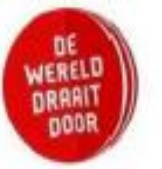

De Wereld Draalt Doer

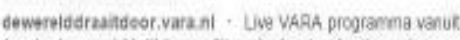
Amsteidam mes Matthis van Nieuwkerk wisseiende gasten nieuss, meda en muzkek owno utzendng gemist? Nu krugbikent

Uhe + cumbent + Share + a monims ago

Figure 3. Magic's LinkedIn

\section{Instagram}

It is good for Magic to also portrait their brand value on their Instagram account by starting to create and post simple creative images, instead of only posting the works Magic has done for clients. They don't have to be really complicated compositing images, but the images should be presented in high quality compositing, fun, creative and inspiring.

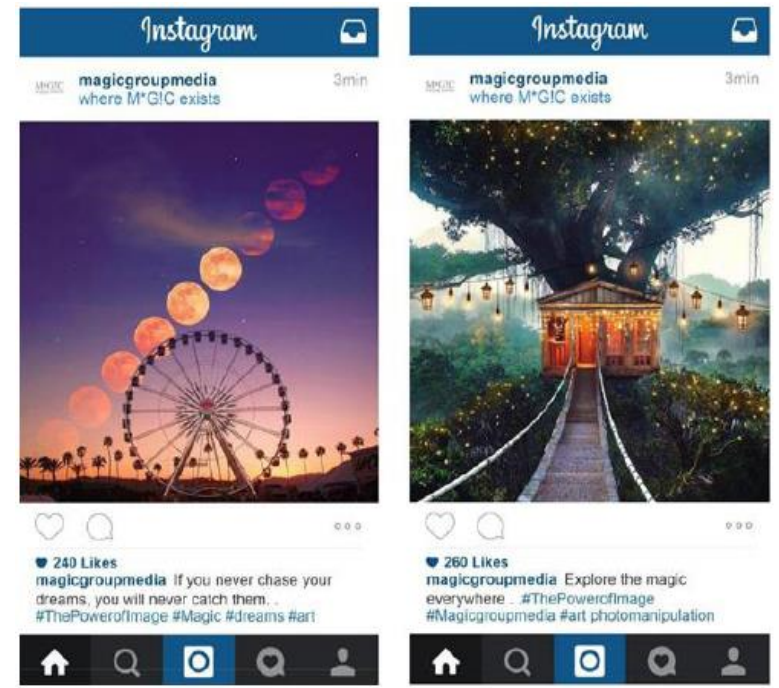

Figure 4. Magic's Instagram Strategy

\section{Pinterest}

Adapting from the competitor's strategy, there are some strategies for posting in Pinterest that Magic can use in order to reach the audience:

1. Pin Vertically. By vertically, use taller images instead of wider ones. Because of Pinterest's original layout that suits portrait images more than landscape images, it will attract more eyeballs.

2. Pin often. The more pins, the more people who are likely to see. Repin, like, other pins/pinners that are relevant to Magic's industry, not only Magic's works.

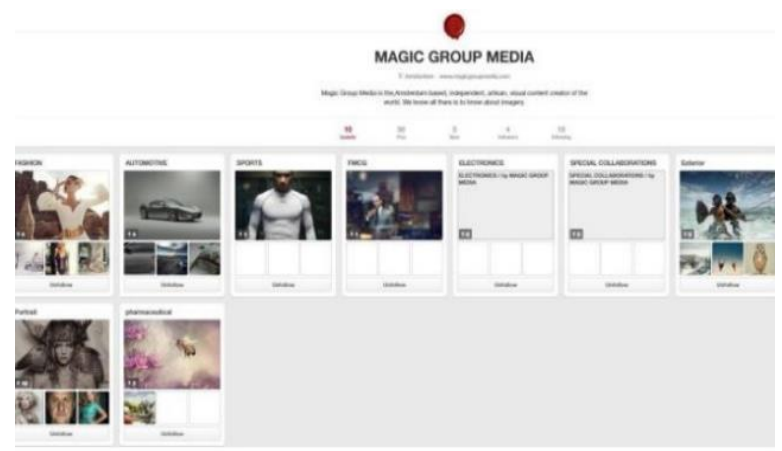

Figure 5. Magic's Pinterest

\section{Facebook}

By posting their activities and their works on Facebook, it keeps their audience informed, updated to what Magic are busy with. By sharing their client's posts, Magic shows that they appreciate, contribute in their client's online presence, and make them feel appreciated. When post their works, Magic also tag the clients who also have Facebook account. In this way, it makes their posts show up on their client's Facebook account, and can trigger other people to look at Magic's Facebook account. 


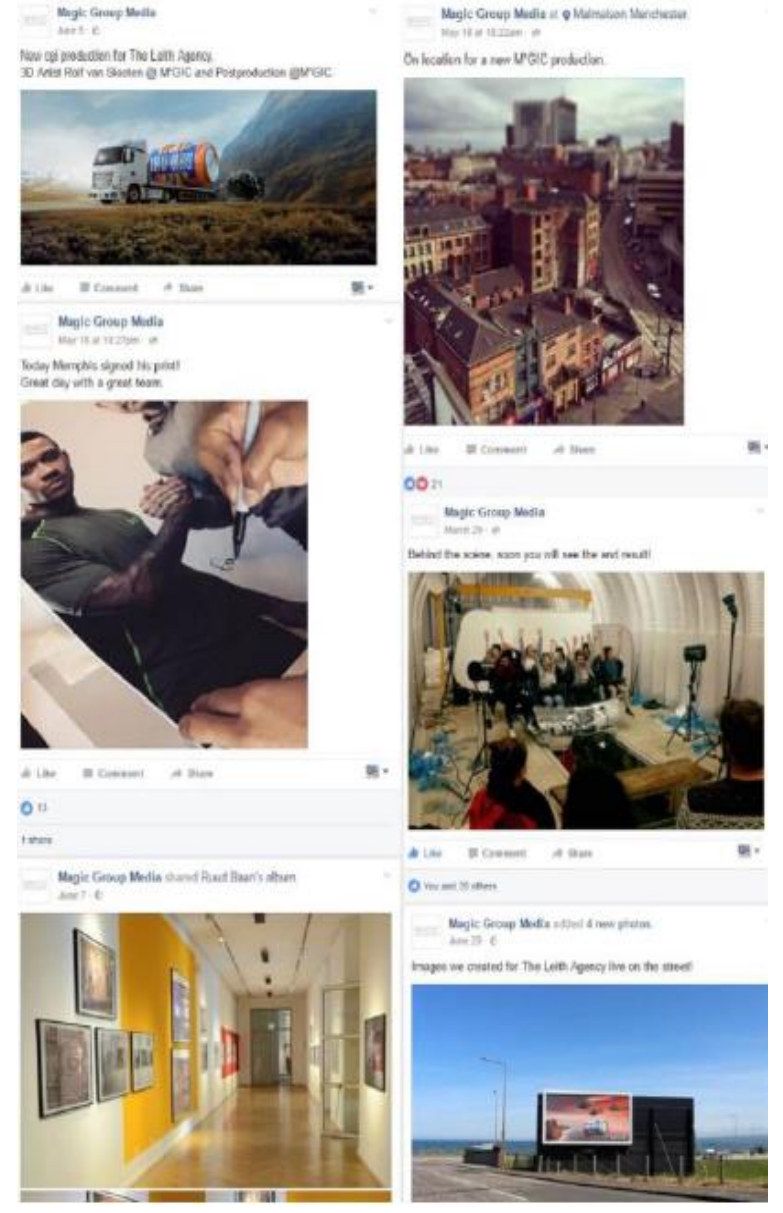

Figure 6. Magic's Facebook Page

Website

Adapting from the competitor's strategy, there are some strategies for Magic's website:

1. Add description about brand value of Magic somewhere in the website that can be seen directly or easily by visitors who visit the website. It might seem obvious, but stating the values on website is the first step to make the visitors aware of what Magic care about. It will make the visitors of the website become aware that Magic have this value they believe in and stand for. It will make the visitors of the website become aware that Magic have this value they believe in and stand for.

2. Add Share Button on every images they put on their website. It's good for Magic to put a Share button on their every portfolio images so the images can be easily shared on social media in order to integrate social media networks and sharing on the website. In this way the visitors become aware that they can share the images easily on social media. It stimulates the visitors to share the images as well. This results in helping increase awareness of Magic's contents, and more people become aware that Magic produces this images.

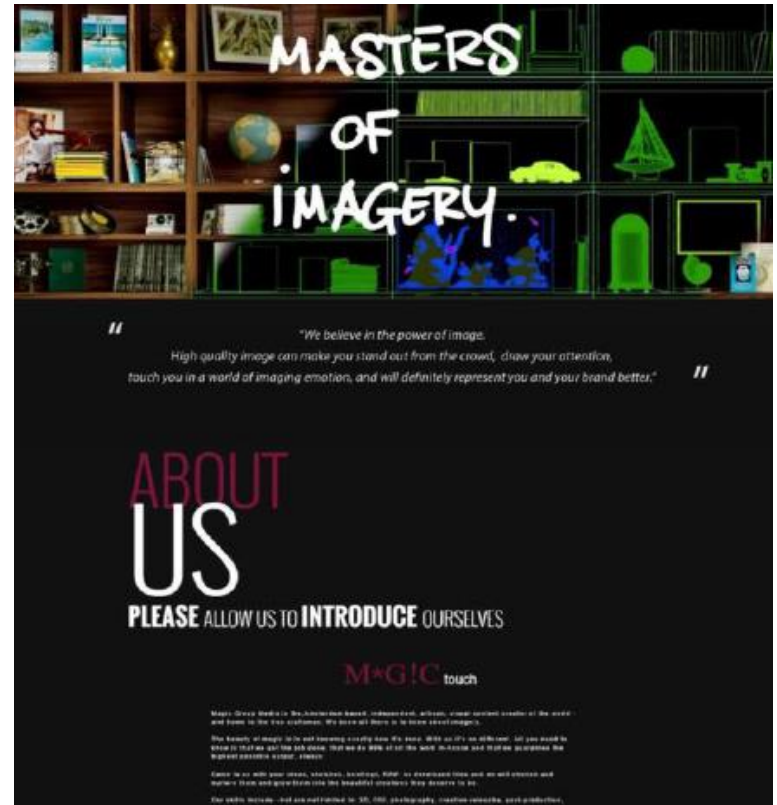

Figure 7. Magic's Website Strategy

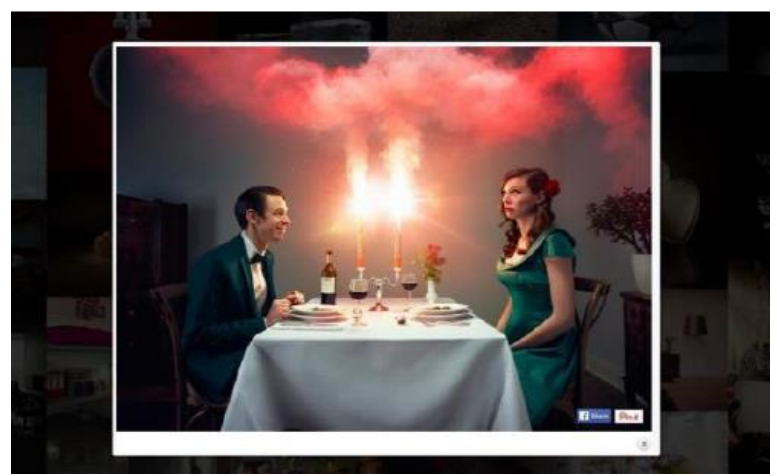

Figure 8. Magic's Website Strategy

3. Add Contact form/box on Magic's website. It offers the visitors a convenient way to contact, inquire Magic about services and products. They can type message straight away without using their email program/web-based email.

4. Give short description about the works/portfolio images. Adapting from the competitor's strategy, it's good to give short description about the works/portfolio images they post on the website. It helps the visitors to understand what Magic's have done and Magic's part on the image.

\section{Feedbacks from Magic}

In this study, the company gives feedbacks about the findings of this study. These are the summary of the feedbacks from Magic:

a. Magic agrees that an event in the near future would be a good way to share their vision and enthuse their (potential) clients about Magic's work/capabilities in a personal and professional way and at the same time discuss developments and interests within the industry. 
b. Magic agrees with the recommended points that this will make the website performs better and will take this on board together with all other points they have. The new website has launched recently and this version is a beta version that still needs tweaking.

c. Magic appreciates the recommendation of the social media that are given. However, Magic is still looking for more possibilities to trigger their social media usage and to be active more in social media, because for now they don't have people who really focus on posting on social media and website.

d. Magic believe they have done very well in their personal selling. The relationship selling that mentioned in the promotional strategy is something they have been doing for years. Magic don't see any critical improvements yet, but they still agree that relationship selling has been a trend for 8 years and that it is important.

To sum up the feedback, Magic appreciates the points and will take them on board. It is good enough for Magic to be taken into consideration. Most of it are tweaking as far as Magic is concerning.

\section{Conclusion}

Based on the result of the promotional strategy that Magic has done before, some of them works well with the existing clients, but Magic evaluates that the promotional strategy needs improvements in order to build a working relationship with new potential clients.

In this study, the author has investigated some important factors such as: stage in product lifecycle, nature of the product, the competitors' actions, target audience profile, the message, the brand value of Magic, to be taken into consideration by Magic in order to establish an effective promotional strategy.

Along with those factors, in order to attract and build a connection with the target audience, communicate the brand value of Magic in the right way is needed because customers are attracted to brands they share values with (Fanaras, 2013). The Golden Circle theory is used to communicate the why of Magic's brand value.

As explained by Porta (2010), with a clearly defined target audience, it is much easier to determine where and how to market your company. Therefore, segmentation is used on Magic's target audience to know the characteristics of the target audience better. In line with that, the author has found in this study that understanding the target audience is strongly related with Magic promotional strategy.

In addition, the author has investigated that nature of products, stage in product life cycle, research on competitors, are also essential to determine the effective promotional strategy. The analysis of aforementioned factors has resulted in 3 promotional elements that can be used by Magic to establish an effective promotional strategy, which are:

1. Event (Public Relations)

2. Website and Social Media (Internet Marketing)

3. Relationship Selling (Personal Selling)

However, as explained by Kokemuller (2012), the selected media, and the formulated messages are keys in building effective promotional strategy. Therefore, Magic should communicate the same message (in this case is the brand value of Magic) through all the elements/tools that are used in the promotional strategy.

The feedbacks from Magic shows that Magic appreciates most of the suggested points and will take them on board. During this study, the author evaluates that there are several things that could be done better for future study, which are the information on the target audience and competitor's promotional strategy can be gathered from better methods. In this way, the data will be more valid and reliable, and the promotional strategy will be more effective.

\section{References}

A. (2015, September 28). An Introduction to an Effective Promotional Mix. Retrieved May 22, 2016, from https://www.cleverism.com/introduction-effective-promotional-mix/

Aaker, D. A. (1991). Managing brand equity: Capitalizing on the value of a brand name. New York: The Free Press.

Advantages of Personal Selling (2016).From Personal Selling Tutorial. KnowThis.com. Retrieved May 22, 2016 from http://www.knowthis.com/ personal-selling/advantages-of-personal-selling

Boundless. Customer Wants and Needs. Boundless Marketing. Boundless, May 26, 2016. Retrieved May 29, 2016 from https://www.boundless.com/marketing/textbooks/boundless-marketing-textbook/introduction-to-marketing-1/ introduction-to-marketing-18/customer-wantsand-needs-107-4453/

Boundless. Impact of the Product Life Cycle on Marketing Strategy. Boundless Marketing. Boundless, May 26, 2016. Retrieved May 29, 2016 from https://www.boundless.com/marketing/textbooks/boundless-marketing-textbook/ products-9/product-life-cycles-69/impact-of- 
the-product-life-cycle-on-marketing-strategy348-10771/

Boundless. Target Market Characteristics. Boundless Marketing. Boundless, May 26, 2016. Retrieved May 29, 2016 from https://www. boundless.com/marketing/textbooks/boundless -marketing-textbook/integrated-marketingcommunications-12/selecting-the-promotionmix-for-a-particular-product-84/target-market-characteristics-421-4126/

Building Brand Equity through Event Marketing. (n.d.). Retrieved May 8, 2016, from https://www. ideasforleaders.com/ideas/building-brandequity-through-event-marketing

Chatterjee, I. (2014, June 28). Advantages and Disadvantages of Direct Marketing. Retrieved May 22, 2016, from http://marketingfaq.net/ direct-marketing/advantages-disadvantagesdirect-marketing/

DeMers, J. (2014, August 11). The Top 10 Benefits of Social Media Marketing. Retrieved May 25, 2016, from http://www.forbes.com/sites/jaysondemers/2014/08/11/the-top-10-benefits-ofsocial-media-marketing/\#1e04b6122a4d

Fanaras, L. (2013, December 16). 5 Major Benefits of a Strong Brand. Retrieved May 22, 2016, from http://www.mill-im.com/creative/5-majorbenefits-strong-brand/

Gibson, J. (2015, January). Word of mouth, social media and viral advertising. Retrieved May 22, 2016, from http://marketing-made-simple.com/ articles/word-of-mouth-advertising.htm

Howard, P. (2013, March 25). Silverpop - How to Deliver a Consistent Message Across All Channels. Retrieved May 22, 2016, from http://www. silverpop.com/blog/How-to-Deliver-a-Consistent-Message-Across-All-Channels

How PR Can Help Build An Organic Audience I Cision. (2016). Retrieved August 06, 2016, from http://www.cision.com/us/2016/04/how-pr-canhelp-build-an-organic-audience/

How to Do Direct Marketing That's Not Annoying. (2013). Retrieved August 17, 2016, from http://www.businessinsider.com/the-explodingimportance-of-direct-marketing-2013-11? $\mathrm{IR}=\mathrm{T}$

Know your customers' needs. (n.d.). Retrieved May 25, 2016, from http://www.infoentrepreneurs. org/en/guides/know-your-customers--needs/

Kokemuller, N. (n.d.). The Importance of Promotional \& Marketing Strategies. Retrieved May 26, 2016, from http://yourbusiness.azcentral.com/ importance-promotional-marketing-strategies-13197.html

Kotler, P., Armstrong, G., Saunders, J., \& Wong, V. (2002). Principles of Marketing (3rd European ed.). London: Prentice-Hall.
Kotler, P., \& Armstrong, G. (2014). Principles of marketing (15th ed.). Upper Saddle River, NJ: Pearson.

Lamb, C. W., Hair, J. F., \& McDaniel, C. D. (2011). Marketing (11th ed.). Mason, OH: Cengage.

Leinbach-Reyhle, N. (2015, June 16). The Single Most Important Reason Why Online Marketing Is More Important Than Ever. Retrieved May 22, 2016, from http://www.forbes.com/ sites/nicoleleinbachreyhle/2015/06/16/thesingle-most-important-reason-why-onlinemarketing-is-more-important-than-ever/\# 499b205b5cc4

Marketing Mix | Promotion in Four P's. (2014). Retrieved April 22, 2016, from https://www. cleverism.com/promotion-four-ps-marketingmix/

Piontek, K. (2015, April 23). How to strengthen your brand and build value. Retrieved May 23, 2016, from https://www.articulatemarketing. com/strengthen-your-brand

Porta, M. (2010). How to Define Your Target Maretket. Retrieved May 25, 2016, from http://www. -market.html

Rouse, M. (2015, February). What is LinkedIn? Definition from WhatIs.com. Retrieved June 14, 2016, from http://whatis.techtarget.com/ definition/LinkedIn

Sinek, S. (2009). Start with why: how great leaders inspire everyone to take action. New York: Penguin Group.

Smith, B. (2014, June 6). Role of Promotion in the Marketing Mix. Retrieved May 16, 2016 from http://www.pfcfulfills.com/whitepapers/role-ofpromotion-in-the-marketing-mix/

Strydom, J. (2004). Introduction to marketing (3rd ed.). Cape Town, South Africa: Juta.

The Marketing Mix and the 4 Ps: Understanding How to Position Your Market Offering. (n.d.). Retrieved May 30, 2016, from https://www. mindtools.com/pages/article/newSTR_94.htm

Warren, J. (2016, May 5). Marketing Your Hospital. Retrieved May 22, 2016, from https://marketingyourhospital.com/

What Impact Does Promotional MIx Have on Your Marketing. (n.d.). Retrieved May 16, 2016, from http://marketing.about.com/od/marketingglossary/g/promomixdef.htm

Why B2B Marketers Should Use Social Media I Martin-Wilbourn Partners. (2014). Retrieved June 05, 2016, from http://mwpartners.com/ why-b2b-marketers-should-use-social-media/

Wheeler, Alina (2012). Designing brand identity (4th ed.). Hoboken, New Jersey: John Wiley \& Sons, Inc. 